\title{
COMPRESSIVE STRENGTH OF RAPID SULFOALUMINATE CEMENT CONCRETE EXPOSED TO ELEVATED TEMPERATURES
}

\author{
JEAN JACQUES KOUADJO TCHEKWAGEP, SHOUDE WANG, ANOL K. MUKHOPADHYAY, \\ "SHIFENG HUANG, XIN CHENG

\begin{abstract}
Shandong Provincial Key Laboratory of Preparation and Measurement of Building Materials,
\end{abstract} \\ University of Jinan, Shandong 250022, China \\ "E-mail: mse_huangsf@ujn.edu.cn
}

Submitted January 14, 2020; accepted March 12, 2020

\begin{abstract}
Keywords: Sulfoaluminate cement concrete, High temperatures, Change strength characteristics, Compressive strength
The compressive strength, modulus and stress-strain behaviour of rapid-hardening sulfoaluminate cement concrete were evaluated as functions of the temperature increase. The compressive strength decreased from 51.3 to $31.1 \mathrm{MPa}$ (around a $39 \%$ reduction) as the temperature increased from $20^{\circ} \mathrm{C}$ to $300^{\circ} \mathrm{C}$ while the specimens burst at $400{ }^{\circ} \mathrm{C}$ before being removed from the furnace. A significant change in the stress-strain behaviour was noticed with an increasing temperature. For the control specimens $\left(20^{\circ} \mathrm{C}\right)$, linear elastic behaviour was followed by plastic deformation before reaching the peak stress prior to failure, but for higher temperatures, the modulus of elasticity was up to $85 \%$ lower and was characterised by a gradually decreasing slope until failure. The micro-structural changes detected by SEM, DTG/TG and XRD were consistent with this pattern. The degree of cracking at the interfacial transition zone and crack-width growth detected by SEM followed a clear trend with the increasing temperature. The transformation of the primary hydration products (e.g., ettringite and $\left.\mathrm{Al}(\mathrm{OH})_{3}\right)$ as detected by XRD and DTG/TG provides a useful explanation of the strength reduction with the increasing temperature up to $300{ }^{\circ} \mathrm{C}$. The vapour pressure evolvement within the specimens at elevated temperatures correlates well with the reduced strength and modulus of elasticity, with a very intense effect at $400^{\circ} \mathrm{C}$.
\end{abstract}

\section{INTRODUCTION}

Since the successful development of sulfoaluminate cement (SAC) by the China Institute of Building Materials Science in 1975, this hydraulic cement has been developed into a high-strength SAC paste, a self-stressing SAC paste, and a rapid-hardening sulfoaluminate cement $[1,2]$ and has been used for the construction of numerous modern buildings in China. Fire is the most common cause of major damage to buildings, but one of the main problems with most types of concrete is its susceptibility to thermally induced deterioration [3]. When concrete experiences very high temperatures, its mechanical properties, such as its compressive strength, modulus of elasticity and stress-strain relationship, can be affected, causing the structure to deteriorate and eventually causing the building to collapse $[4,5,6]$. There have been many reports on such collapses due to fire in China's Hengyang and Hengzhou provinces, as well as in chemical and metallurgical industry facilities in Henan province, where concrete structural elements made with SAC are in close proximity to furnaces $[7,8]$.

After a building has been exposed to fire or extreme heat, its load carrying capacity must be determined before a decision on whether to rebuild the damaged structure is made $[9,10]$. Published literature on the behaviour of rapid sulfoaluminate cement concrete (SACC) at eleva- ted temperatures is very limited. This study investigates the effect of extended exposure to elevated temperatures on the SACC's strength and behaviour, so as to understand the changes in the mineral structure that occur due to such exposure. Quantifying the SACC's ability to handle heat and its disintegration period, along with more fully understanding the effect of the elevated temperatures on the mineralogy of the rapid SACC element, will help us to identify the rapid SACC's critical temperature and predict possible failures.

\section{EXPERIMENTAL}

Materials and mix design

Consistent with Chinese GB/T500081-2002 standard test methods, cube-shaped $100 \mathrm{~mm}$ samples were cast to examine the effects of elevated temperature on the compressive strength of rapid SACC. In addition, $20 \mathrm{~mm}$ cube specimens were produced to represent the SAC paste so as to understand the dehydration phase that occurs as the temperature increases [11]. These specimens were demoulded after 24 hours; they were then cured in a curing room with standard humidity and temperature for 28 days [12]. The rapid-hardening sulfoaluminate cement R.SAC-42.5 was used for all the preparations; its oxide composition is shown in Table 1. 
Tchekwagep J. K., Wang S., Mukhopadhyay A. K., Huang S., Cheng X.

Table 1. Full analysis - the Vac28mm of the sulfoaluminate cement used (KCps).

\begin{tabular}{cccccccccccc}
\hline $\mathrm{CaO}$ & $\mathrm{Al}_{2} \mathrm{O}_{3}$ & $\mathrm{SO}_{3}$ & $\mathrm{SiO}_{2}$ & $\mathrm{Fe}_{2} \mathrm{O}_{3}$ & $\mathrm{MgO}$ & $\mathrm{TiO}_{2}$ & $\mathrm{~K}_{2} \mathrm{O}$ & $\mathrm{SrO}$ & $\mathrm{Na}_{2} \mathrm{O}$ & $\mathrm{Cl}$ & $\mathrm{P}_{2} \mathrm{O}_{5}$ \\
\hline $\mathrm{S} 45.28 \%$ & $17.51 \%$ & $15.76 \%$ & $9.19 \%$ & $2.50 \%$ & $1.90 \%$ & $0.75 \%$ & $0.48 \%$ & $0.17 \%$ & $0.19 \%$ & $0.11 \%$ & $0.10 \%$ \\
\hline
\end{tabular}

It is a cement with compressive strength and flexural strength of $72.1 \mathrm{MPa}$ and $50.2 \mathrm{MPa}$ at 28 days, respectively. Concrete strength grade $\mathrm{C} 40$ was used, with an initial setting time of 30 - 50 min and a final setting time of 40 - $90 \mathrm{~min}$. The fine aggregate used was river quartz sand with a density of $5.218 \mathrm{~g} \cdot \mathrm{cm}^{-3}$ and a fineness modulus of 2.6. The coarse aggregate was crushed limestone with a density of $6.093 \mathrm{~g} \cdot \mathrm{cm}^{-3}$; the aggregate gradations are shown in Table 2. The workability was improved by

Table 2. The aggregate gradation.

\begin{tabular}{ccccc}
\hline \multicolumn{2}{c}{ Limestone $[5-25] \mathrm{mm}$} & & \multicolumn{2}{c}{ Quartz sand $[0.6-4.75] \mathrm{mm}$} \\
\cline { 4 - 5 } Sieve size & \% passing & & Sieve size & $\%$ passing \\
\hline $0-5$ & $5 \%$ & $0-0.6$ & $20 \%$ \\
$5-10$ & $25 \%$ & $0.6-1.18$ & $45 \%$ \\
$10-15$ & $50 \%$ & $1.18-2.36$ & $25 \%$ \\
$15-20$ & $15 \%$ & $2.36-4.75$ & $10 \%$ \\
$20-25$ & $5 \%$ & - & - \\
\hline
\end{tabular}

Table 3. The sulfoaluminate cement concrete and the sulfoaluminate cement paste mix proportions.

\begin{tabular}{lcc}
\hline & $\begin{array}{c}\text { SACC Unit weight } \\
\left(\text { per }^{3}\right)\end{array}$ & $\begin{array}{c}\text { SAC Unit weight } \\
\left(\text { per }^{3}\right)\end{array}$ \\
\hline Cement & 430 & 300 \\
Water & 160 & 120 \\
Gravel 5 - 25 & 975 & - \\
Quartz sand 1.6 - 2.6 & 835 & - \\
Retarder & 4.3 & - \\
w/c & 0.4 & 0.4 \\
\hline
\end{tabular}

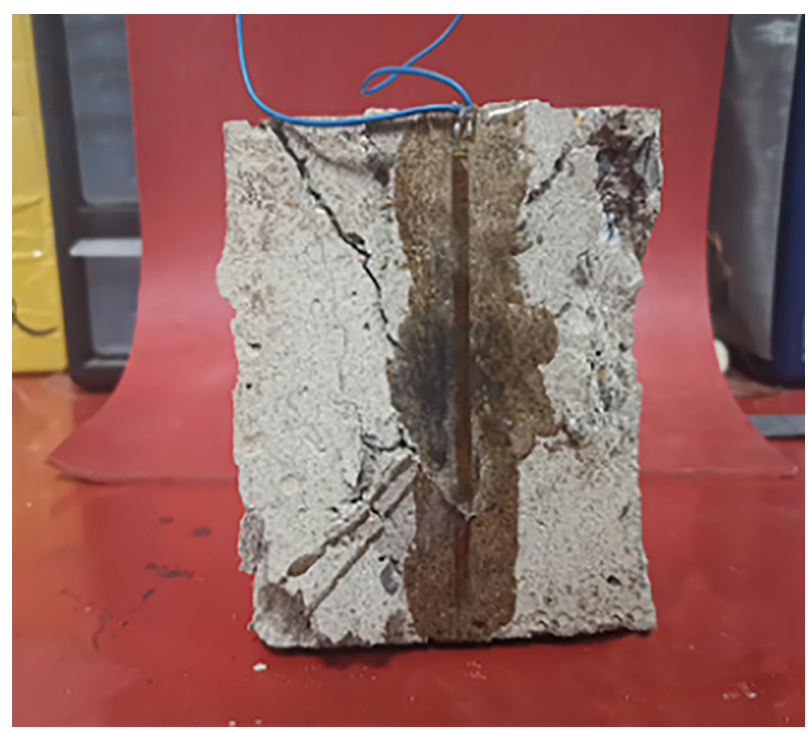

a) $20^{\circ} \mathrm{C}$ adding a polycarboxylate superplasticiser, which also acts as a chemical retardant for SAC. The do-sage of this additive was calculated based on the cement volume. The mix proportions are shown in Table 3.

\section{Test stand and Methods}

To measure the effect of the elevated temperatures on the SACC, the different samples were exposed to various temperatures for $4 \mathrm{hrs}$. [13, 14]. The samples were removed from the standard curing room under humidity control for the cement concrete room temperature $(\mathrm{T}=$ $=23 \pm 2{ }^{\circ} \mathrm{C}, \mathrm{RH}>95 \%$ [15]) after 28 days; they were then air-dried for 5 days in the laboratory. The samples were then placed into an electric furnace for exposure at different temperatures (i.e., 100, 200, 300, 400, and $500{ }^{\circ} \mathrm{C}$ ) with a heating rate of $4{ }^{\circ} \mathrm{C} \cdot \mathrm{min}^{-1}$ and an exposure time of $4 \mathrm{hrs}$. This exposure time was found to be adequate for the complete dehydration of $\mathrm{Al}(\mathrm{OH})_{3}$ and other related dehydration reactions, as well as other thermally induced physical changes [16].

The compressive strength testing for all the specimens was conducted using a servo-hydraulic compressive testing machine at the load rate of $0.3 \mathrm{kN} \cdot \mathrm{s}^{-1}$. The compressive test was performed using two sets of samples. The first set was tested immediately after removal from the furnace, and the second set was allowed to cool for 30 minutes while a strain gauge (BF120$80 \mathrm{AA})[17,18]$ was installed on the surface, see Figure 1, followed by load application and recording of the stress-

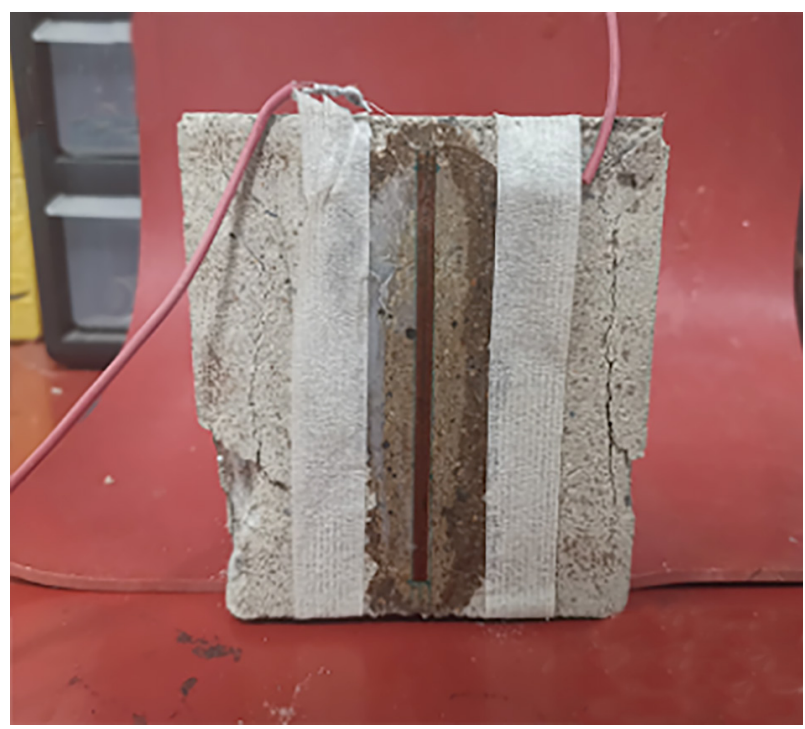

b) $100{ }^{\circ} \mathrm{C}$

Figure 1. The SACC samples showing the installed strain gauge and characteristics of the crack patterns 30 minutes after the removal from the furnace and loaded, at temperatures of $20,100,200$ and $300{ }^{\circ} \mathrm{C}$. (Continue on next page) 


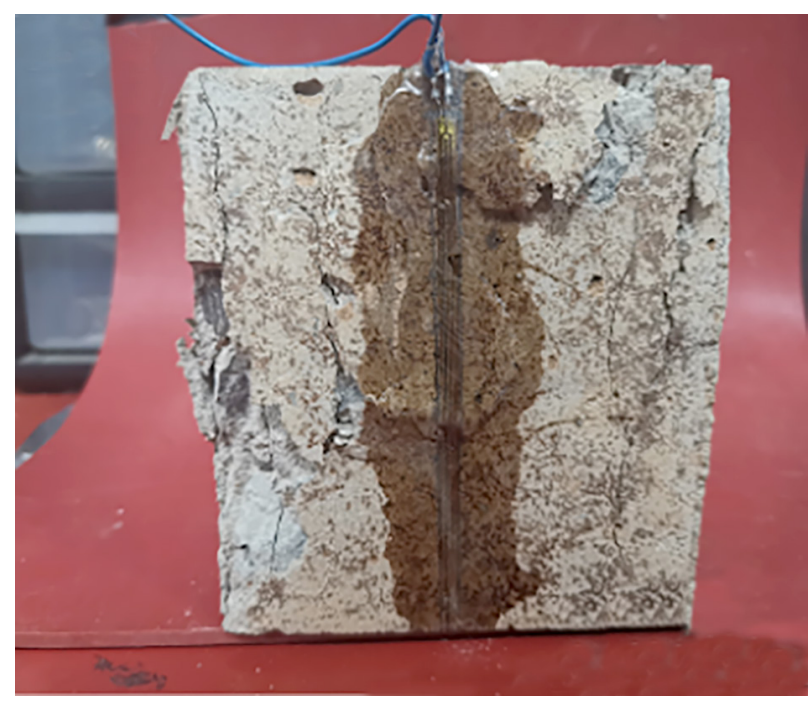

c) $200{ }^{\circ} \mathrm{C}$

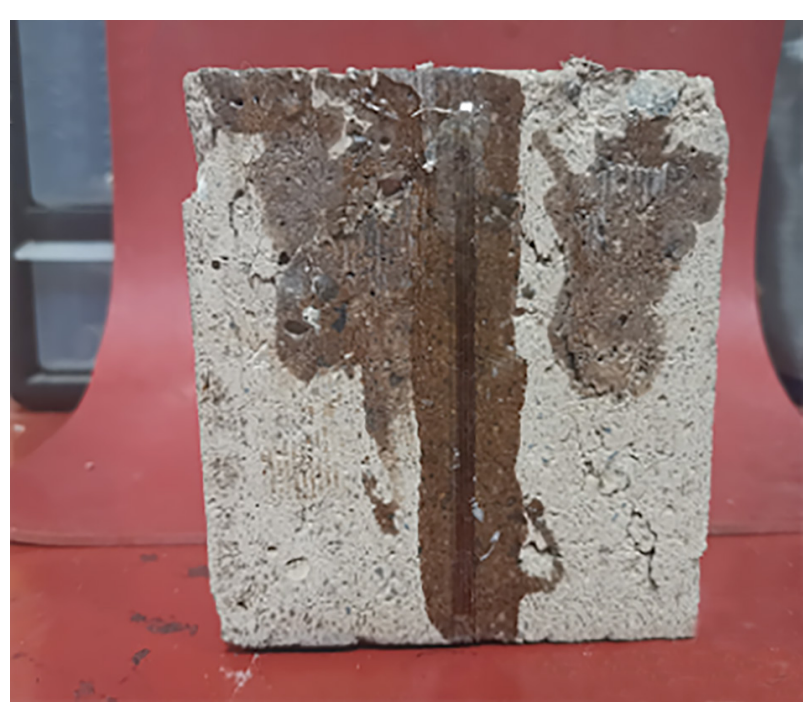

d) $300^{\circ} \mathrm{C}$

Figure 1. The SACC samples showing the installed strain gauge and characteristics of the crack patterns 30 minutes after the removal from the furnace and loaded, at temperatures of $20,100,200$ and $300{ }^{\circ} \mathrm{C}$.

strain behaviour of the tested SACC. Six specimens (three for the compressive strength and three for the stress-strain behaviour) were tested for each designated temperature. The stress-strain behaviour was measured using a linear transformer (ASMC2 series resistance, version number V2.1) [19] strain gauge.

\section{RESULTS AND DISCUSSION}

\section{Compressive strength}

The results (calculated as an average for each set of samples) show that the compressive strength decreased as the temperature increased, and after an additional cooling time of 30 minutes, the decrease was greater, as shown in Figure 2. Cooling for $30 \mathrm{~min}$ introduces a temperature gradient with a relatively lower temperature outside than the core temperature for both the concrete and paste specimens. This temperature gradient creates a stress differential between the core and surface of the specimen, which is fatal for the concrete specimens because of their greater size. Additionally, the concrete specimen displayed stress concentrations, see Figure 3, at the interfacial transition zone, again more so than the paste because of its different thermal behaviour of the sand and cement paste. These stress concentrations could lead to micro-crack formations and a strength reduction for the concrete specimens. As a result, the concrete specimens, after $30 \mathrm{~min}$ of cooling, always showed lower strength levels than the specimens tested before the cooling.

However, the paste specimens actually showed an increase in strength at $200{ }^{\circ} \mathrm{C}$ after cooling and no difference in strength at $500{ }^{\circ} \mathrm{C}$. As the paste specimens

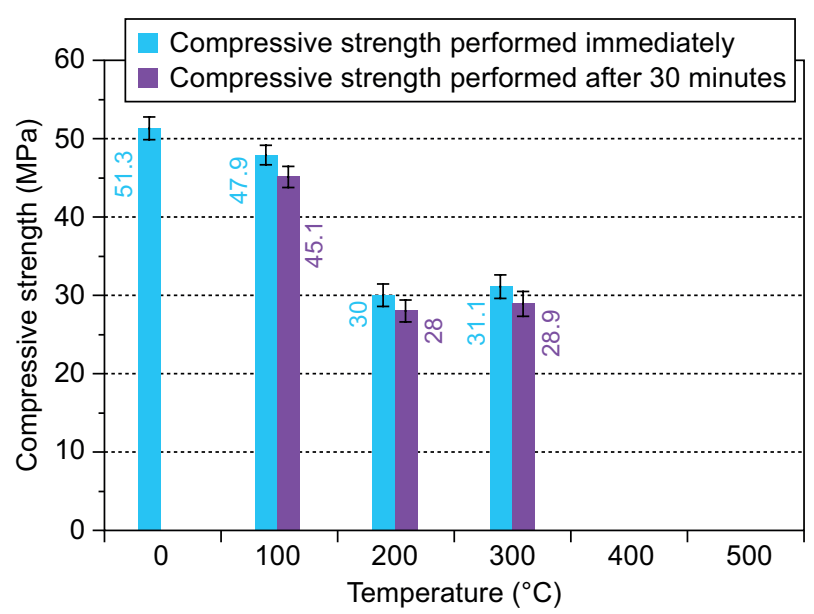

a) SACC

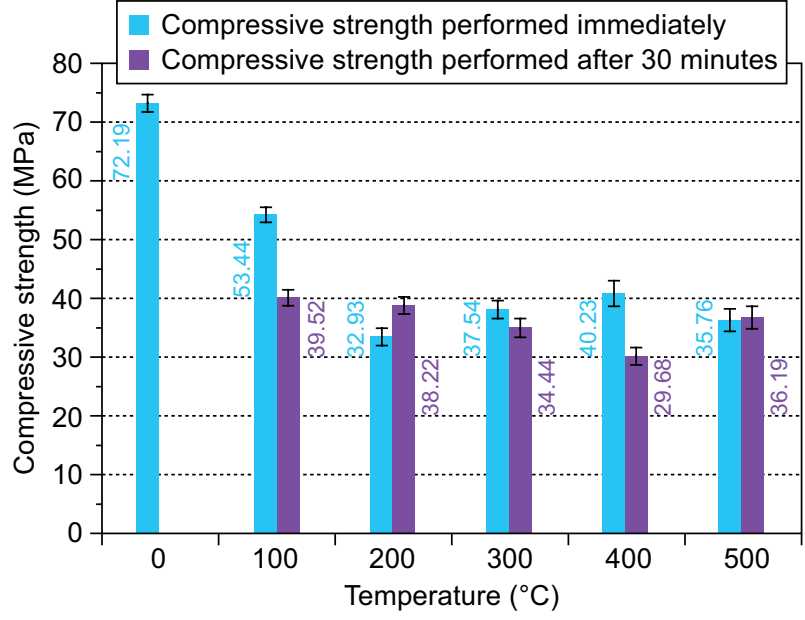

b) SAC

Figure 2. The compressive strengths of the sulfoaluminate concrete and paste vs. the temperature. 
were smaller in size, see Figure 4, and there were no aggregate effects, the temperature difference may not have caused any consistent change in strength. The overall decrease in strength with the increasing

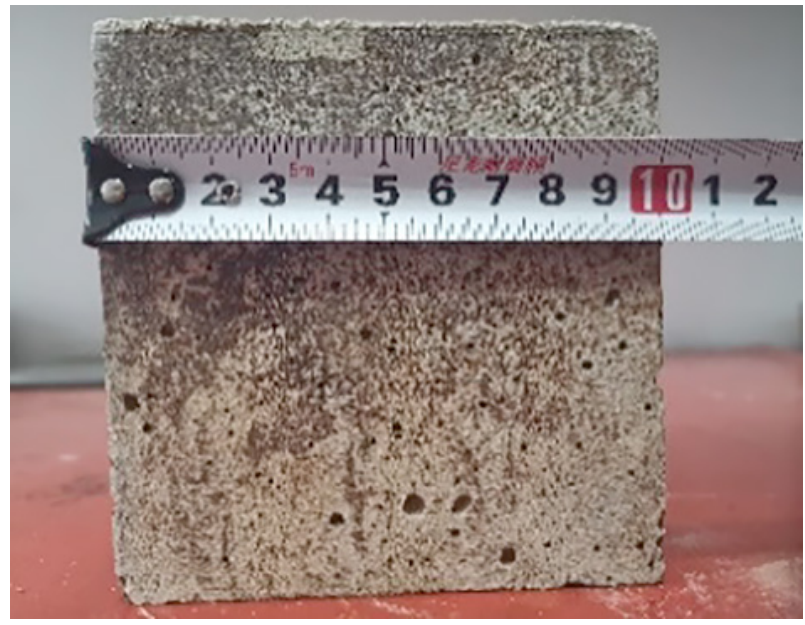

a) $20{ }^{\circ} \mathrm{C}$

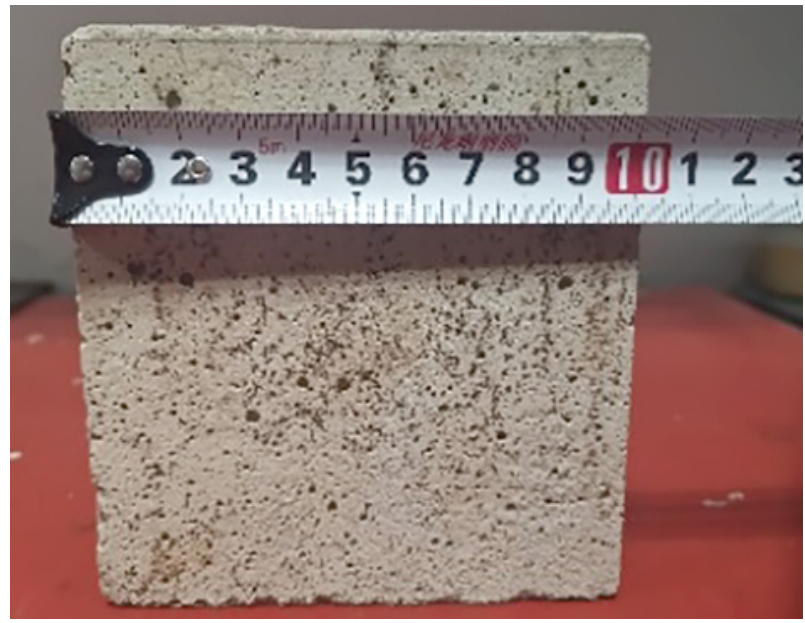

c) $200{ }^{\circ} \mathrm{C}$ temperatures is a combined effect of the phase transformation (the creation of porous micro-structures) and vapour pressure (related to the dehydration reaction of the hydration products formed at room temperature).

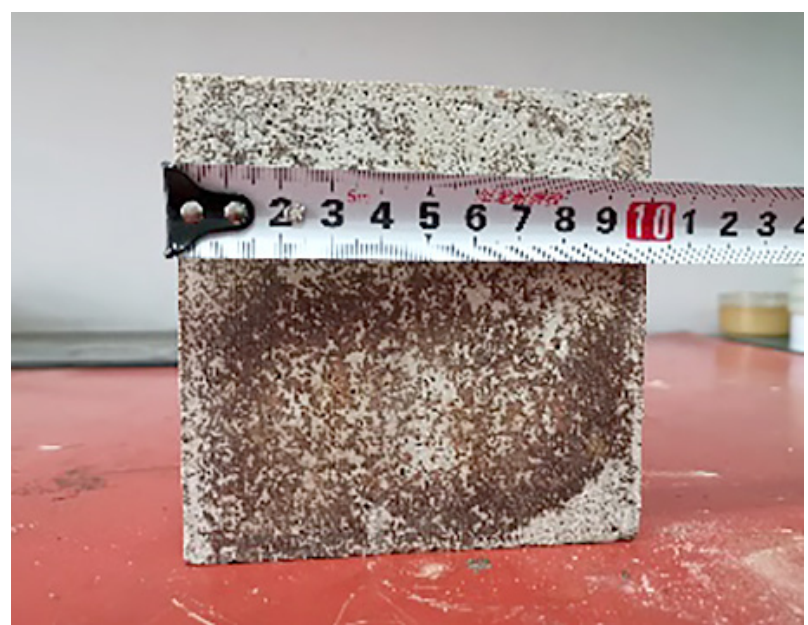

b) $100{ }^{\circ} \mathrm{C}$

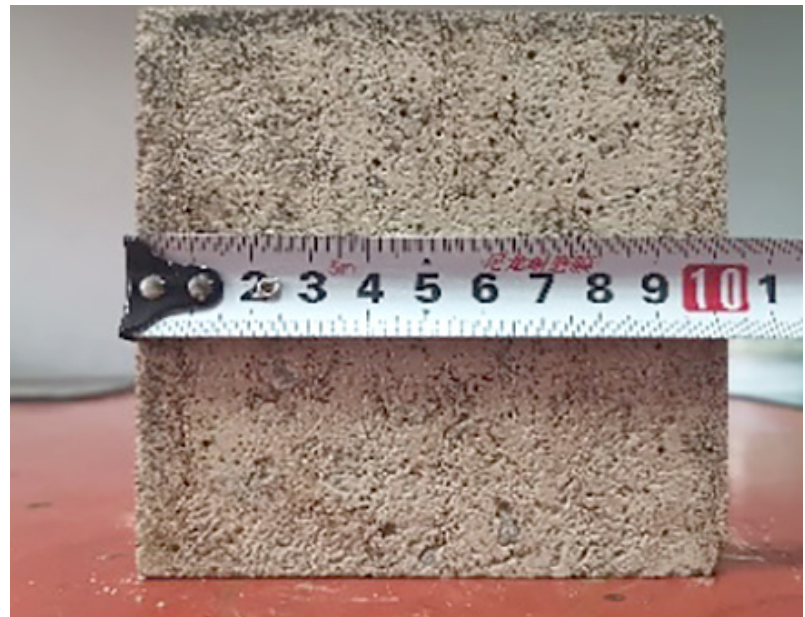

d) $300{ }^{\circ} \mathrm{C}$

Figure 3. The appearance of the SACC specimens immediately after removal from the furnace.

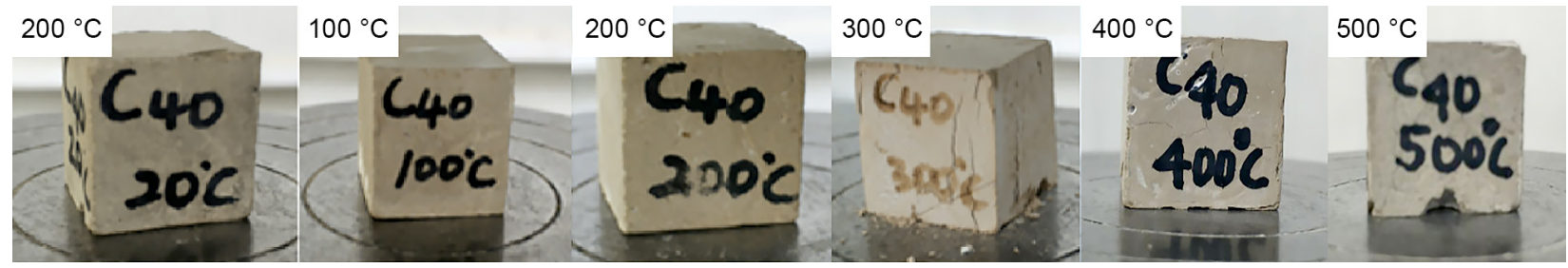

a) the appearance of the SAC paste specimens immediately after removal from the furnace

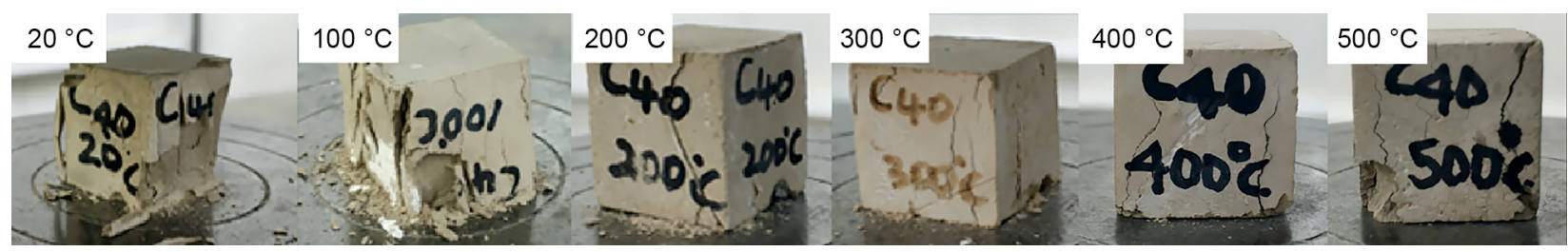

b) the appearance of the SAC paste specimens immediately after removal from the loaded corresponding

Figure 4. The appearance characteristics of the crack pattern 30 minutes after removing the SAC paste specimens from the furnace and loaded corresponding to $20,100,200$ and $300{ }^{\circ} \mathrm{C}$. 
The strength change due to phase transformation with the increasing temperature was manifested by both the concrete and paste specimens. However, the effect due to the vapour pressure build up was more intense in the concrete specimens because of their larger dimensions. As a result, the concrete specimens failed at $400{ }^{\circ} \mathrm{C}$, but the paste specimens did not fail at either $400{ }^{\circ} \mathrm{C}$ or $500{ }^{\circ} \mathrm{C}$.

The sequence of the change in the strength with the increasing temperature due to the phase transformation as well as the vapour pressure build up is explained below:

- The decomposition of ettringite at around $100-120{ }^{\circ} \mathrm{C}$ produced a monosulfate (AFm) and caused an increase in porosity, which may have been related to the strength reduction in both types of specimens, with greater effects in the paste specimens.

- Between $165{ }^{\circ} \mathrm{C}$ and $185{ }^{\circ} \mathrm{C}$, the decomposition of AFm to gypsum and aluminate caused similar effects in both the paste and concrete specimens.

- The $\mathrm{Al}(\mathrm{OH})_{3}$ to $\mathrm{Al}_{2} \mathrm{O}_{3}+\mathrm{H}_{2} \mathrm{O}$ decomposition between $280{ }^{\circ} \mathrm{C}$ and $300{ }^{\circ} \mathrm{C}$ created the phase, which was responsible for the slight strength increase in both the paste and concrete specimens.

- There was not much phase transformation after $300^{\circ} \mathrm{C}$ in the paste specimens, and the pressure build up effect was negligible. As a result, the paste specimens did not fail with a further temperature increase from $300{ }^{\circ} \mathrm{C}$ to $500{ }^{\circ} \mathrm{C}$. In contrast, the specimens showed a slight increase in strength from $300{ }^{\circ} \mathrm{C}$ to $400{ }^{\circ} \mathrm{C}$.
- It seems that the pressure build-up effects were not substantial for the concrete specimens up to $300{ }^{\circ} \mathrm{C}$. However, this effect became acute after $300{ }^{\circ} \mathrm{C}$, and the specimens failed completely at $400{ }^{\circ} \mathrm{C}$.

The appearance of the SAC paste specimens immediately after removal from the furnace.

The compressive strength of the sample tested at $20{ }^{\circ} \mathrm{C}$ had the highest compressive strength with large cracks, spalling, and support failure, see Figure 5a and $\mathrm{b}$, because of the cracks resulting from the dry shrinkage of as much as $1 \%$ of the volume and the applied load, whereas the samples heated to $200{ }^{\circ} \mathrm{C}$ and $300{ }^{\circ} \mathrm{C}$ had a lower compressive strength with narrow cracks, yet they held up despite the damage, see Figure $5 \mathrm{c}$ and $\mathrm{d}$. Nevertheless, the initial thermal crack caused by the heat decreased the stress span of the first straight line. At $400{ }^{\circ} \mathrm{C}$, all the SACC specimens broke explosively, as shown in Figure 5e and $\mathrm{f}$, inside the electric resistance furnace. As indicated by Wanga and Chen [20, 21, 22], SAC has an unstable density, adding to the vapour pressure evolvement inside the tested specimen. For this reason, as observed with the samples at $400{ }^{\circ} \mathrm{C}$, a complete collapse can result. The elevated temperatures caused the volume of the samples to shrink, leading to cracks. When the crack force stopping the volume change can no longer apply sufficient resistance, wide cracks occur. This is the reason for the observed phenomenon.

The average thermal expansion coefficient of the quartz river sand and limestone gravel used for the experiments at the different temperatures were also calculated $[23,24]$. Figure 6 shows the stereo microscopic

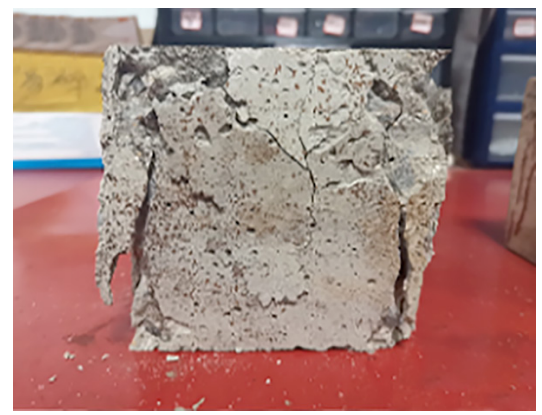

a) $20{ }^{\circ} \mathrm{C}$

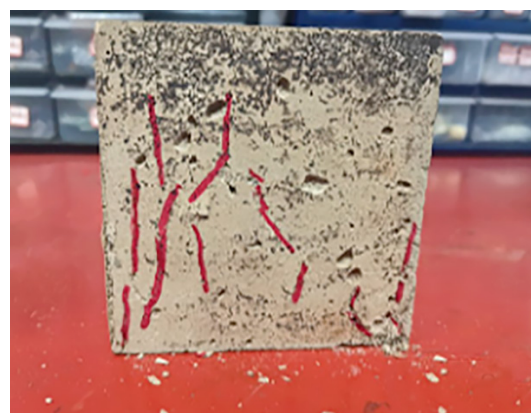

d) $300{ }^{\circ} \mathrm{C}$

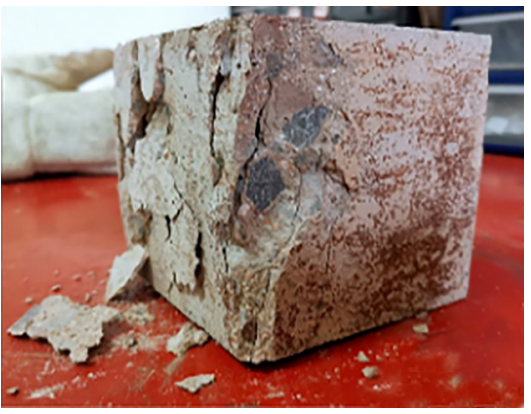

b) $100{ }^{\circ} \mathrm{C}$

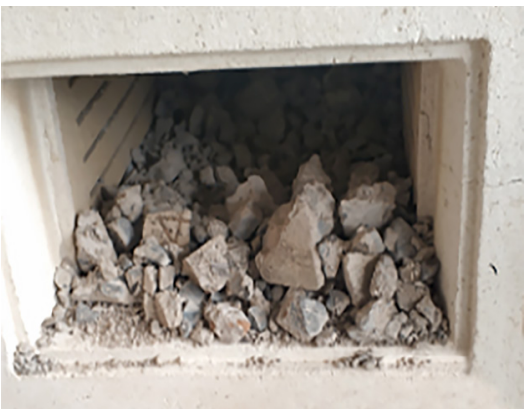

e) $400{ }^{\circ} \mathrm{C}$

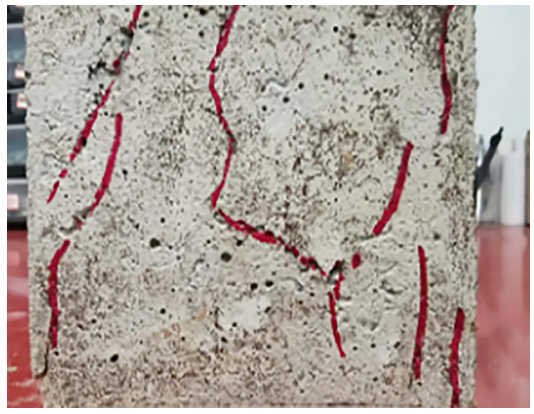

c) $200{ }^{\circ} \mathrm{C}$

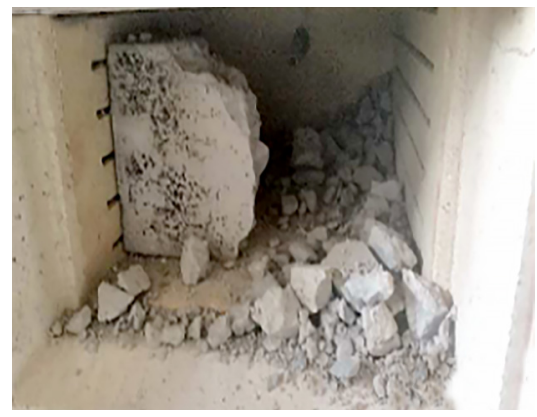

f) $500{ }^{\circ} \mathrm{C}$

Figure 5. The nature of the damage (crack pattern) of the SAC concrete specimens after immediately being removed from the furnace and loaded, at temperatures of $20,100,200$, and $300^{\circ} \mathrm{C}$. 


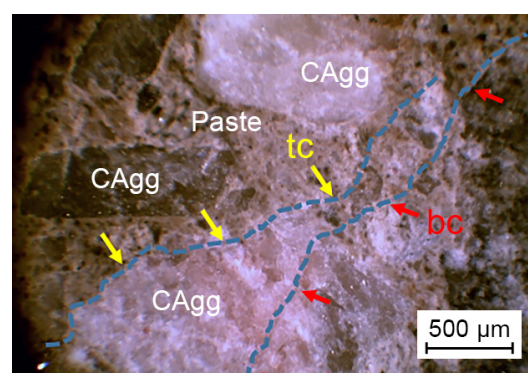

a) $100{ }^{\circ} \mathrm{C}$

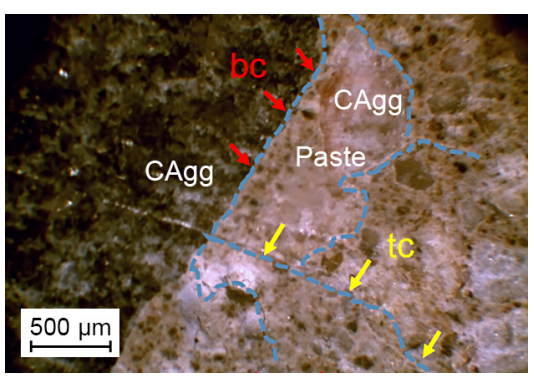

b) $200{ }^{\circ} \mathrm{C}$

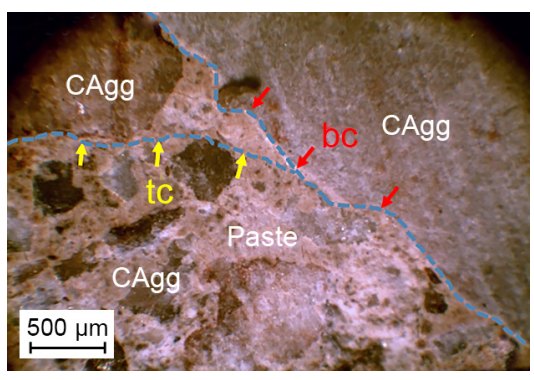

c) $300{ }^{\circ} \mathrm{C}$

Figure 6. The stereo microscopic appearance of the SACC sample after removal from the furnace following exposure to the different temperatures for $4 \mathrm{hrs}$. The images show heated induction microcracks; $\mathrm{BC}=$ boundary crack, $\mathrm{TC}=$ transgranular crack.

appearance image of the SACC samples immediately after removal from the furnace, following exposure at the different temperatures for $4 \mathrm{hrs}$. The images show the propagation of micro-cracks through the coarse aggregate and the paste, displaying a pattern of the cracking at the interfacial transition zone with changes in the crack widths. The expansion of the limestone as the temperature increased varied from $1.00 \times 10^{-3}$ to $2.5 \times 10^{-2} /{ }^{\circ} \mathrm{C}$; this was less pronounced than the expansion of the quartz sand, which ranged from $2.4 \times 10^{-3}$ to $6.00 \times 10^{-2} /{ }^{\circ} \mathrm{C}$ from $100{ }^{\circ} \mathrm{C}$ to $300{ }^{\circ} \mathrm{C}$. The rising temperature caused the limestone to grow in size, resulting in the shrinkage of the SAC paste bordering it, due to the imbalance of the thermal stresses between the limestone, quartz, and very dense SAC paste $[25,26]$. The average mass changes (in grams) of the SACC were 0.119 at $100{ }^{\circ} \mathrm{C}, 1.302$ at $200{ }^{\circ} \mathrm{C}$, and 1.573 at $300{ }^{\circ} \mathrm{C}$; for the SAC paste, they were 0.67 at $100{ }^{\circ} \mathrm{C}, 2.73$ at $200{ }^{\circ} \mathrm{C}$, 3.7 at $300{ }^{\circ} \mathrm{C}$, and 3.71 at $400{ }^{\circ} \mathrm{C}$, relative to the initial mass at $20{ }^{\circ} \mathrm{C}$. Therefore, a comparative assessment between the paste and the concrete provides a better way to understand the changes in the strength.

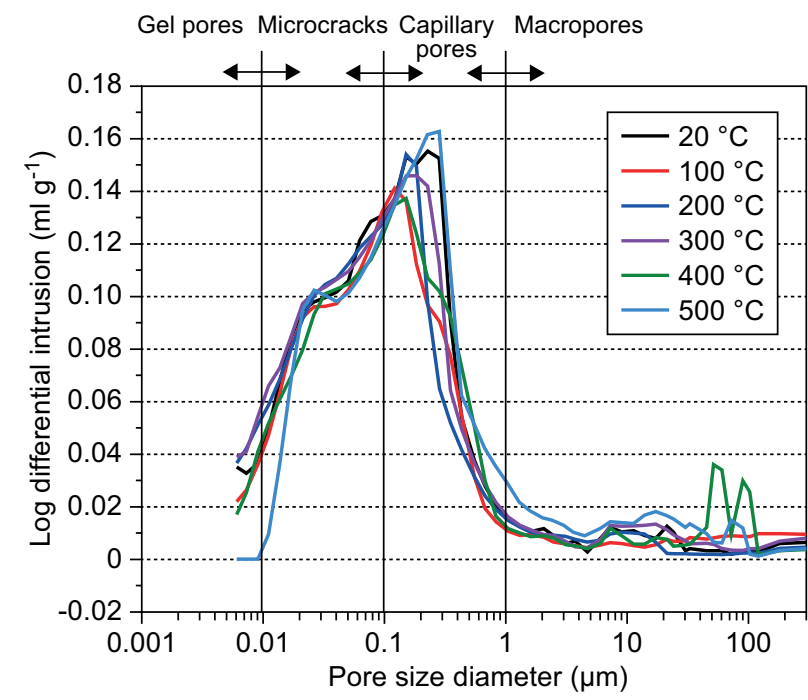

a)

\section{Pore structure analysis}

In order to confirm the results of the compressive strength changes in terms of the microstructural modifications partly caused by the dehydration of the SAC paste inside the samples, mercury intrusion porosimetry tests were realised on the paste samples. The pore structure analysis of the SAC pastes heated for $4 \mathrm{hrs}$ at various temperatures (i.e., 100, 200, 300, 400, and $500{ }^{\circ} \mathrm{C}$ ) are presented in Figure 7 . The curves of the logarithmic differential intrusion vs the pore size, see Figure $7 \mathrm{a}$, show that the increasing temperature made the differential intrusion curves move towards the lower pore sizes. The results show that increasing temperature may slightly increase the micro cracks which is in accordance with the stereo microscopic observation, which show less growth in the number of wide pores and an increase in the number of light pores. The total porosity of the pastes varied from $32.12 \%$ for $20{ }^{\circ} \mathrm{C}$, $34.75 \%$ for $100{ }^{\circ} \mathrm{C}, 34.27 \%$ for $200{ }^{\circ} \mathrm{C}, 36.04 \%$ for $300{ }^{\circ} \mathrm{C}, 35.15 \%$ for $400{ }^{\circ} \mathrm{C}$ and $35.41 \%$ for $500{ }^{\circ} \mathrm{C}$, see Figure $7 \mathrm{~b}$, that correlate with the lower strength measurements recorded for the paste after cooling.

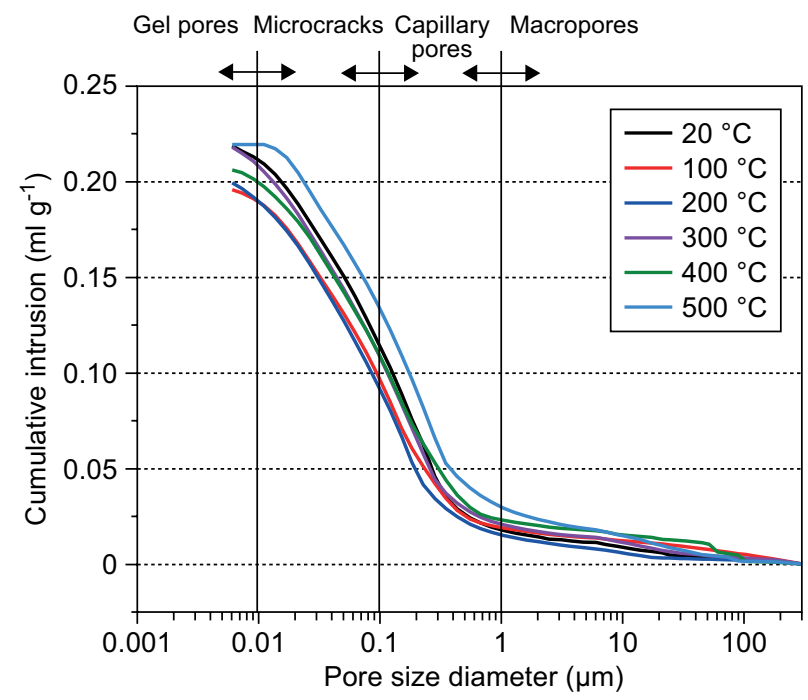

b)

Figure 7. The pore diameter distribution of the SAC pastes heated for $4 \mathrm{~h}$ at the different temperatures: a) the log differential intrusion curves, b) the cumulative intrusion curves. 
There were few changes in the percentage of the porosity between $100{ }^{\circ} \mathrm{C}$ and $200{ }^{\circ} \mathrm{C}$ that correlate with the decomposition of the ettringite. It increases at $300{ }^{\circ} \mathrm{C}$ and in accord with the decreasing strength observed as well at $400{ }^{\circ} \mathrm{C}$ and $500{ }^{\circ} \mathrm{C}$ where the hydration phase is in accordance with the porosity and strength recorded.

\section{Modulus of elasticity}

The modulus of elasticity $(E)$, was determined by dividing the stress by the strain obtained while loading the specimens that were equipped with a strain gauge. Its variations over the average wide range $68.69 \times 10^{-3} \mathrm{MPa}$ to $12.61 \times 10^{-3} \mathrm{MPa}$ consequently decrease nearly $85 \%$ over the range of temperature exposures, as shown in Figure 8. Therefore, as illustrated, at the different temperatures, the SACC became deformed. The lowest values of the moduli of elasticity testify to the flexibility of the SACC between $100{ }^{\circ} \mathrm{C}$ and $300^{\circ} \mathrm{C}$, as its shape changed considerably.

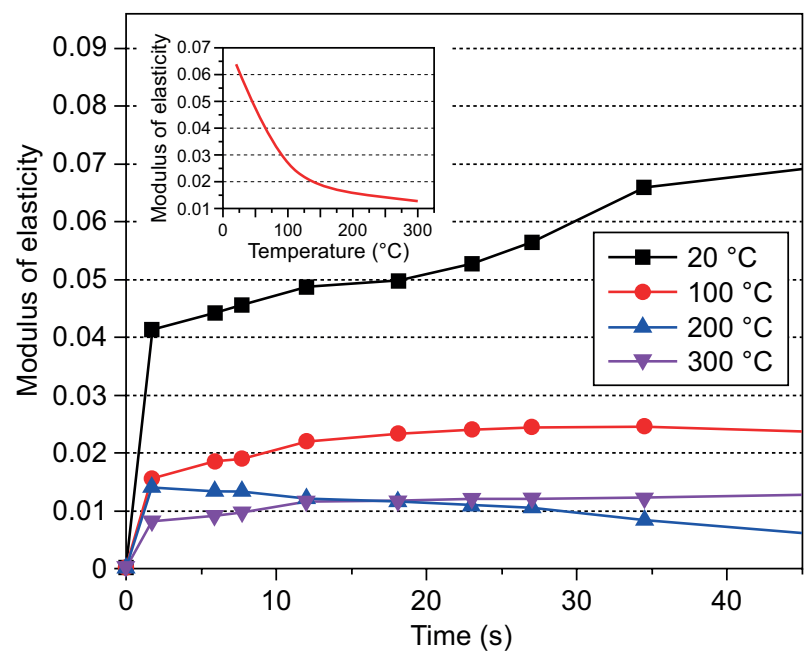

Figure 8 . The modulus of elasticity of the SAC concrete vs. the heated temperatures.

\section{Stress-strain}

The temperature exposure has a notable impact on the stress-strain relationship; the slope of the stressstrain deformation curve decreases with an increasing temperature. For the control (at $20^{\circ} \mathrm{C}$ ), linear elastic behaviour (initially steep slope, followed by shallow slope) is followed by plastic deformation before reaching the peak stress prior to failure. At $100{ }^{\circ} \mathrm{C}$ and $300{ }^{\circ} \mathrm{C}$, the characteristic trend is elastic behaviour starting with a shallow slope (shallower than at $20^{\circ} \mathrm{C}$ ) followed by a gradual decrease in the slope till it fails (similar to the visco-elastic behaviour). However, at $200{ }^{\circ} \mathrm{C}$, the initial elastic behaviour was similar to that at $300^{\circ} \mathrm{C}$, but then changed promptly to a very low slope (i.e., the large change in the strain with a smaller change in stress, more of a visco-elastic and plastic nature) with smaller decrease in the slope until failure.

The stress-strain curve of the SAC concrete at $100{ }^{\circ} \mathrm{C}, 200{ }^{\circ} \mathrm{C}$, and $300{ }^{\circ} \mathrm{C}$ distinctly shows that the strain has a tendency to decline and its peak evidently descends and moves toward the right-hand side as the testing temperature increases. The variations in the stress-strain curves can be partially attributed to the increased occurrence of micro-pores and capillary voids with a diameter of between 2 and $50 \mathrm{~nm}$ caused by the thermal changes to the microstructure as discussed previously in Section "Pore structure analysis ". These pores act as stress concentrators as they open under the applied load affecting the degree of cracking at the aggregate-paste interfaces and increasing the crack widths in the paste (See, Section "SEM analysis and XRD"). In addition to the development of micro-pores and capillaries, the elevated temperature exposure causes differential strains due to the mismatched thermal expansion of the constituents of the concrete and the elevated internal stress within the pore spaces due to vapour pressure resulting in a significant residual stress, residual strain, and micro-cracking throughout the specimen. When considered together, these effects explain the trend of the stress-strain curves, which are perceptibly flatter when the specimen is exposed to higher temperatures as observed in Figure 9.

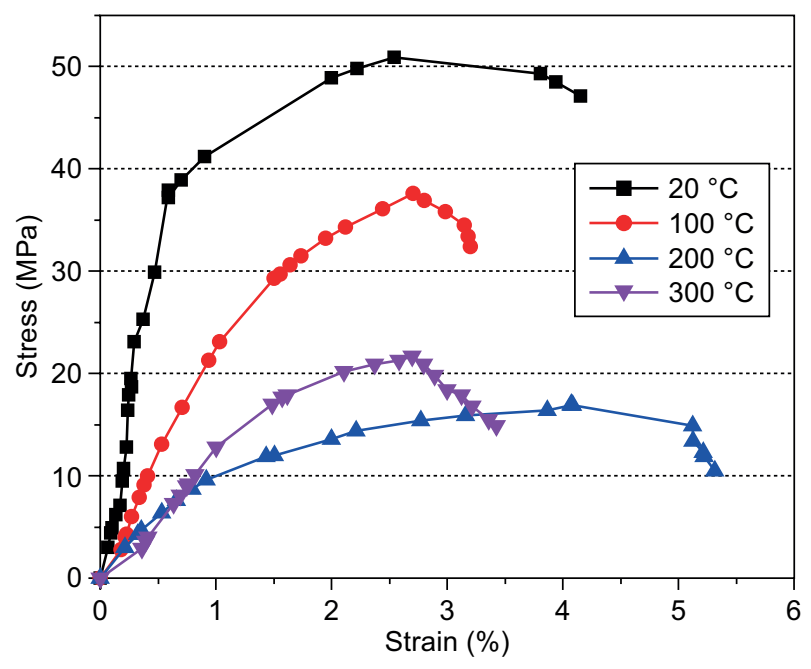

Figure 9. The compressive stress-strain curve of the SAC concrete after being heated and loaded.

\section{SEM analysis and XRD}

A SEM was performed to obtain a greater understanding of the recorded strength depletion and the different failure behaviours during the damage of each sample on a microstructural level. X-ray diffraction was performed on the samples of the SAC concrete and SAC paste at the different designed temperatures. The SEM observations of the microstructure pattern of each 
sample exposed to the different temperatures showed a clear trend of an increasing numbers of wide cracks with increasing temperatures up to $300{ }^{\circ} \mathrm{C}$. Loannou [27, 28] argued that this kind of cracking might be formed during heating at the different temperatures because of the imbalanced internal stresses between the disproportionately expanding limestone and quartz sand, which compress the SAC paste that surrounded them. The performed SEMs, see Figure 10, display a pattern of different compacting at different temperatures. Between $100{ }^{\circ} \mathrm{C}$ and $200{ }^{\circ} \mathrm{C}$, we observed pores connecting with a diameter of between 2 and $50 \mathrm{~nm}$, fine cracks by location and large wide cracks. At $300^{\circ} \mathrm{C}$, better compactness is observed, with fewer cracks of large width, which correlated with the small gain in strength recorded at $300{ }^{\circ} \mathrm{C}$.

The X-ray shows that, as the temperature increased, the element of each sample was different. Figure 11 shows that between $100{ }^{\circ} \mathrm{C}$ and $200^{\circ} \mathrm{C}$, one can remark the dehydration of the AFt inside the $\mathrm{SAC}$ paste and $\mathrm{AH}_{3}$ gel, which breaks them into an unreactive mineral inside the SAC and plays no role when it comes to bonding the surrounding aggregates together.

The decrease in strength might be attributable, based on the X-ray evidence, to the dehydration pattern recorded for the ettringite and $\mathrm{Al}(\mathrm{OH})_{3}$, which disappeared between $100{ }^{\circ} \mathrm{C}$ and about $300{ }^{\circ} \mathrm{C}$, and the appearance of $\mathrm{C}_{3} \mathrm{~A} \cdot \mathrm{CaSO}_{4} \cdot 12 \mathrm{H}_{2} \mathrm{O}$ and $\mathrm{Al}_{2} \mathrm{O}_{3}$, respectively. The $\mathrm{XRD}$ analysis results show that there was no AFm in the hydration product. Therefore, it can be concluded that the hydration product is $\mathrm{AH}_{3}$, corresponding to the endothermic valley at $290^{\circ} \mathrm{C}$, and the other endothermic valley corresponds to AFm [29, 30], correlating to the lower measurements in the compressive strength and decreasing stress-strain trend between $100{ }^{\circ} \mathrm{C}$ and $300{ }^{\circ} \mathrm{C}$. The endothermic peaks (DTG/TG curves) higher than $700{ }^{\circ} \mathrm{C}$ are due to the further dehydration of $\mathrm{C}-\mathrm{S}-\mathrm{H}$ and the decomposition of $\mathrm{CaCO}_{3}$ inside the cement. Furthermore, the DTA/TG patterns highlighted the chemical changes inside the SAC mineralogy, which were manifested by the reduction in the intensity of the compounds $\mathrm{AFt}, \mathrm{AFm}$ and $\mathrm{AH}_{3}$ gel. All of these

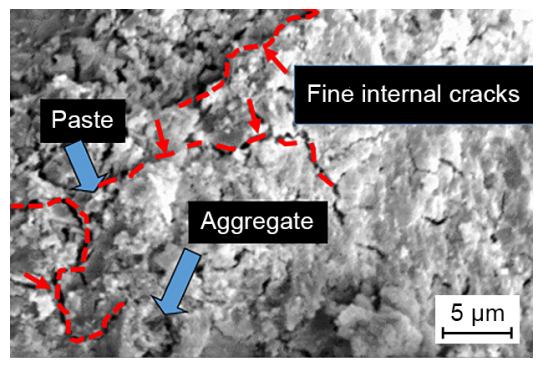

a) $100{ }^{\circ} \mathrm{C}$

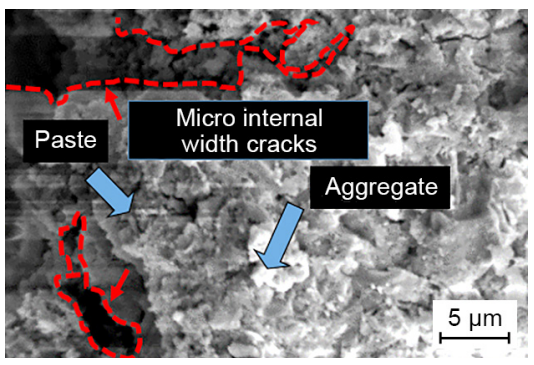

b) $200{ }^{\circ} \mathrm{C}$

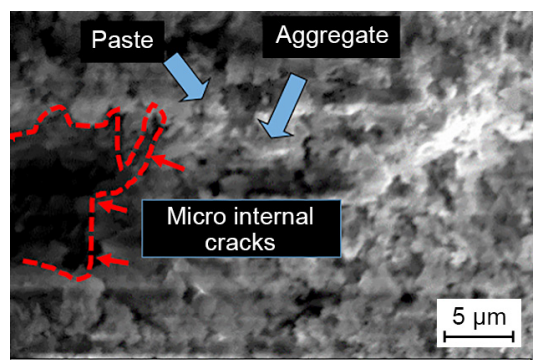

c) $300{ }^{\circ} \mathrm{C}$

Figure 10. The SEM patterns of the different samples after removal from the furnace following exposure of the SAC concrete to different temperatures for $4 \mathrm{hrs}$.

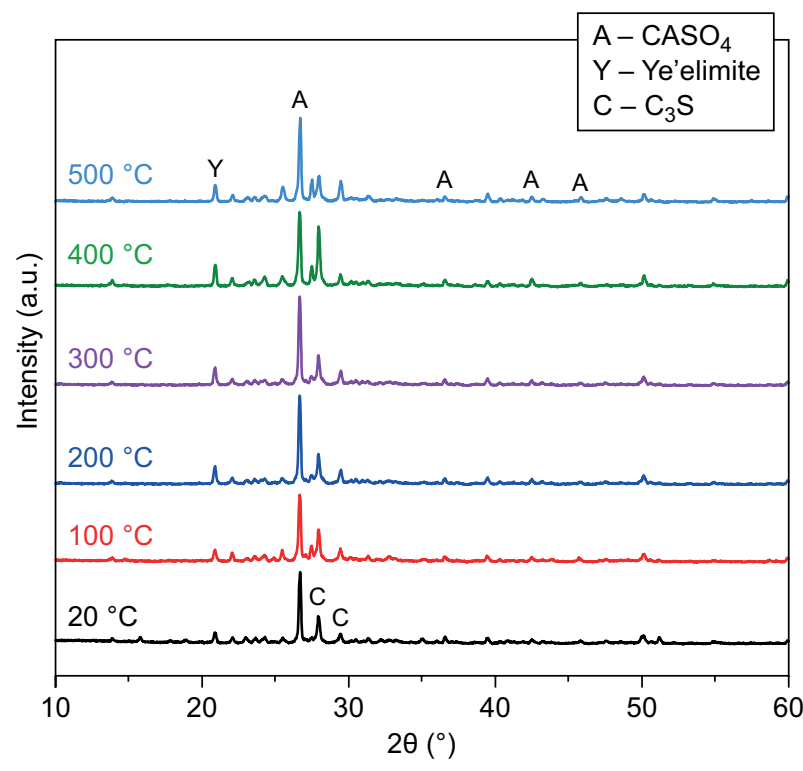

a) $\mathrm{SAC}$ concrete

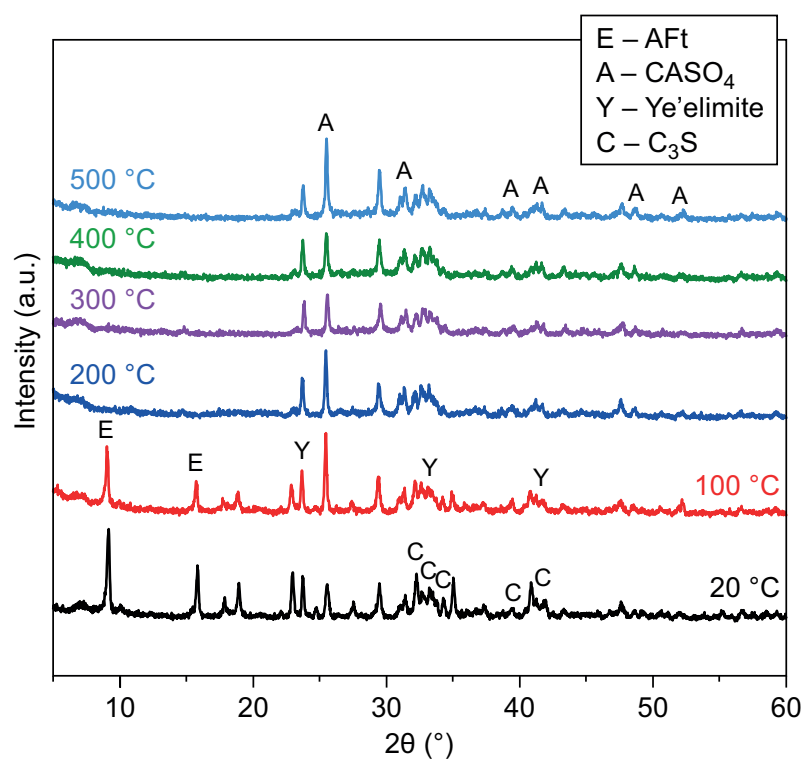

b) SAC paste

Figure 11. The XRD spectrums of the diffraction patterns of the hydrated SAC concrete (a) and SAC paste (b) at the different temperatures. 
hydration products are important crystals giving strength to the SAC to bond with the aggregates. Figure 12 shows the DTA/TG curves of the different samples when heated, indicating a loss in the intensity of the minerals contained by the SAC as the temperature increased from $200{ }^{\circ} \mathrm{C}$ to $500{ }^{\circ} \mathrm{C}$, to say nothing of the $\mathrm{AH}_{3}$ crystal mineral strength of the cement that remains. Figure 12a and b clearly illustrate the different mineralogy-damaged behaviour of the SAC as the temperature increased; this behaviour correlated to the decrease in the strength range temperatures.

The testing revealed a very rapid decrease in the compressive strength of the SAC concrete after exposure to the $100{ }^{\circ} \mathrm{C}, 200{ }^{\circ} \mathrm{C}$, and $300{ }^{\circ} \mathrm{C}$ temperatures. $42 \%$ of the SAC concrete is $<$ half its initial compressive strength after heating to $200{ }^{\circ} \mathrm{C}$, thus it cannot be repaired, but should be demolished. Normal concrete can be repaired because the structural integrity remains acceptable after heating at the same temperature [31], which remains at $>90 \%$ of its compressive strength after heating at $200{ }^{\circ} \mathrm{C}$ [32]. The SAC concrete initially might have a higher compressive strength, therefore it performed better than the normal concrete in terms of the load carrying capacity of the structure. However, according to a previous study, the normal concrete had a constant decrease in the strength [33], whereas the SAC concrete, in our study, did not. Therefore, normal concrete has a better resilience strength rating as the temperatures increase than the SAC concrete.

\section{CONCLUSION}

This research article shows the results of the understanding of the strength (compressive strength, modulus of elasticity, and stress-strain) changes of the SAC concrete after being exposed to elevated temperatures (i.e., $100{ }^{\circ} \mathrm{C}, 200{ }^{\circ} \mathrm{C}, 300{ }^{\circ} \mathrm{C}, 400{ }^{\circ} \mathrm{C}$ and $500{ }^{\circ} \mathrm{C}$ ).

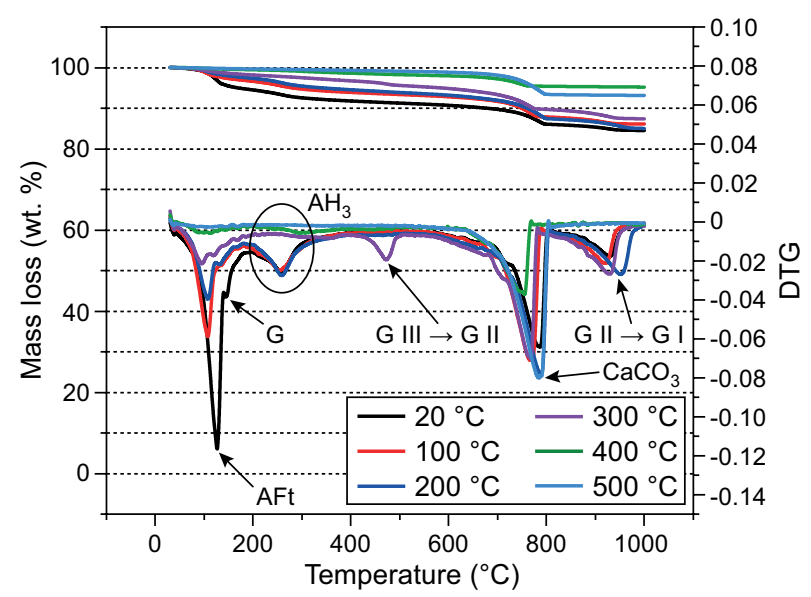

a) $\mathrm{SAC}$ concrete
- The compressive strength of the samples immediately loaded was reduced to $7 \%$ at $100{ }^{\circ} \mathrm{C}, 42 \%$ at $200{ }^{\circ} \mathrm{C}$, and $39 \%$ at $300{ }^{\circ} \mathrm{C}$; $30 \mathrm{~min}$ later, it was $12 \%$ for the sample heated to $100{ }^{\circ} \mathrm{C}, 45 \%$ for $200{ }^{\circ} \mathrm{C}$, and $43 \%$ for $300{ }^{\circ} \mathrm{C}$ (all the percentages are relative to the initial strength). At the testing temperatures of 200 and $300{ }^{\circ} \mathrm{C}$, see Figure 4, several internal cracks formed inside the samples during the heating before being loaded, and the stress span of the first straight line decreased the carrying load structure value. The flexibility of the sample, illustrated by the low modulus of elasticity as the temperature increased, could be a useful quality when the structure cracks during exposure to fire.

- The failure pattern of the SAC concrete samples at 100, 200 and $300{ }^{\circ} \mathrm{C}$ was not similar to that at the normal temperatures, see Figure 1a. When the testing temperature was between 100 and $300{ }^{\circ} \mathrm{C}$, as shown in Figure 1b, c and d, an inclined main crack distinctly materialised on the surface of the samples, the inclination angle was wide, the area of cracking was long and drawn out, and irregular cracks were dispersed on the other parts of the surface. The SAC concrete exposed at $400{ }^{\circ} \mathrm{C}$ was completely destroyed by an explosion inside the furnace. The damage was not because of the higher density of the SAC alone, but also because of its poor mineralogy disintegration of the $\mathrm{AH}_{3}$ gel strengthening the ingredient's comportment and weakening the bond with the aggregates by its dehydration and the effect of vapour pressure development inside the tested specimen (a function of a specimen's dimension).

- Finally, an analysis through DTG/TG and X-ray of the SAC paste alone at the same designated temperatures showed that the AFt, AFm, and $\mathrm{AH}_{3}$ gel, played an important role in bonding the quartz sand and limestone together. Their dehydration phases as the temperature

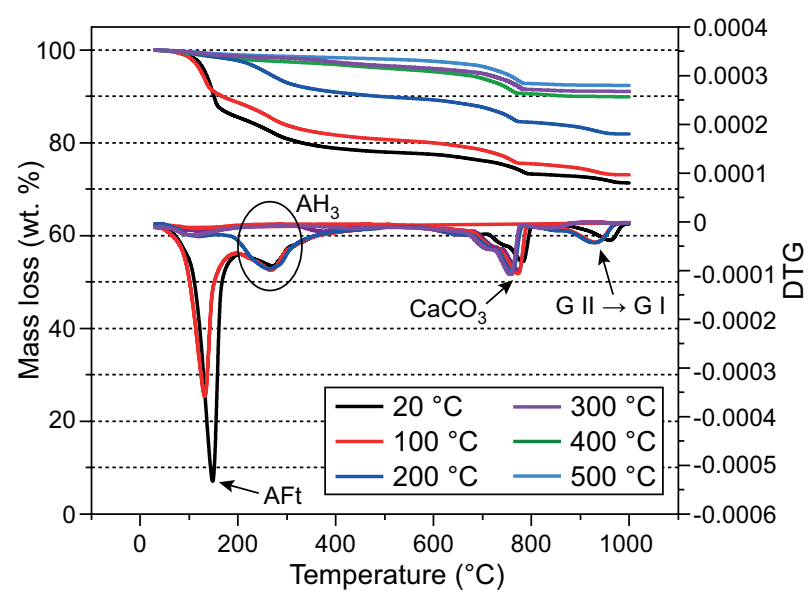

b) SAC paste

Figure 12. The DTG/TG diagram patterns of the sulfoaluminate cement concrete (a) and SAC paste (b) at the different temperatures. 
increased correlated to the decreasing strength at those temperature ranges, as validated by the porosity tests of the cement paste. The $20 \times 20 \times 20 \mathrm{~mm} \mathrm{SAC} \mathrm{paste}$ blocks did not explode when subjected to elevated temperatures, perhaps partly due to their smaller size. Samples of larger sizes still need to be explored for their fire resistance.

- The study results indicate that the mechanical properties of SAC concrete remain fairly stable up to a temperature of $200{ }^{\circ} \mathrm{C}$. However, beyond that, the origin of the aggregates may play an important role in the SAC concrete behaviour because the SAC will experience disintegration. The mechanical properties, such as the compressive strength, modulus of elasticity, stress-strain, and mass weight decrease when exposed to high temperatures.

\section{Acknowledgements}

This work was supported by the National Natural Science Foundation of China (No.51761145023 and 51632003), the Taishan Scholars Program, and the Case-by-Case Project for Top Outstanding Talents of Jinan

\section{REFERENCE}

1. Péra J., Ambroise J. (2003): New applications of calcium sulfoaluminate cement. Cement and Concrete Research, 34(4), 671-676. doi: 10.1016/j.cemconres.2003.10.019

2. Scrivener K.L.., Cabiron J.-L., Letourneux R.. (1999): High-performance concretes from calcium aluminate cements. Concrete and Cement, 29(8), 1215-1223. doi: 10.1016/ S0008-8846 (99)00103-9

3. Tam T. K., Tsang H. L., Lui G. C., Fong N. K., Chow W. K. (2014): Fire safety strategies for existing rock caverns in Hong Kong. Tunnelling and underground space technology, 43, 78-87. doi: 10.1016/j.tust.2014.04.001

4. Kaewunruen S., Wu L., Goto K., Najih Y. M. (2018): Vulnerability of structural concrete to extreme climate variances. MDPI journal, 231(1), 6-40. doi: 10.3390/ cli6020040.2018.12.05

5. Sanad A.M., Lamont S., Usmani A.S., Rotter J.M. (2000): Structure behavior in fire compartment under different heating regimes - part 1 (slab thermal gradients). Fire Safety Journal, 35(2), 91-116. doi: 10.1016/S0379-7112 (00)00024-2

6. Yu J., Qian J., Tang J., Ji Z., Fan Y. (2019): Effect of ettringite seed crystals on the properties of calcium sulphoaluminate cement. Construction and Building Materials, 207(20), 249-257. doi: 10.1016/j.conbuildmat.2019.02.130

7. Bernardo G., Telesca A., Valenti G.L. (2006): A porosimetric study of calcium sulphaluminate cement paste cured at early ages. Cement and Concrete Research, 438(2), 1042-1047. doi: 10.2016/j.cemconres.2006.02.014

8. Janotka I., Nurnbergerova T. (2005): Effect of temperature on quantity of the cement paste and high- strength concrete with silica fume Nuclear Engineering and Design, 99, 2019-2032. doi: 10.1016/j.nucengdes.2005.05.011
9. Arioz O. (2007): Effect of elevated temperatures on properties of concrete. Fire Safety Journal, 234, 516-522. doi: 10.1016/j.firesaf.2007.01.003

10. Naus D. (2006). The effect of elevated temperature on concrete materials and structures: a literature review. Division of Engineering Technology, Office of Nuclear Regulatory Research, US Nuclear Regulatory Commission. doi: $10.2172 / 974590$

11. Jiang C., Zeng M., Cao Y., Bi Y., Wang L., Wang Y, (2019): The history, logic and trends of the discipline of safety science in China. Safety Science, 116, 137-148. doi: 10.1016/j.ssci.2019.03.005

12. Liu C., Luo J., Li Q., Gao S., Su D., Zhang J., Chen S.. (2019): Calcination of green high-belite sulphoaluminate cement (GHSC) and performance optimizations of GHSC-based foamed concrete. Materials \& Design, 182(15), 107-986. doi: 10.1016/j.matdes.2019.107986

13. Ali M. M., Gopal S., Handoo S. K. (1994): Studies on the formation kinetics of calcium sulphoaluminate. Cement and Concrete Research, 24(4), 715-720. doi: 10.1016/00088846(94)90196-1

14. Wang S., Jian L., Shu Z., Wang J., Hua X., Chen L. (2019): Preparation, properties and hydration process of low temperature nano-composite cement slurry. Construction and Building Materials, 205, 434-442. doi: 10.1016/j.conbuildmat.2019.02.049

15. Elkhadiri I., Palacios M., Puertas F. (2009): Effect of curing temperature on cement hydration. Ceramics - Silikáty, 53, 65-75.

16. Berenguer R. A., de Holanda Barbosa A., Monteiro E. C. B., de Almeida Oliveira R., da Costa e Silva A.J. (2016): Analysis of a concrete structure that was exposed to fires in the metropalitan region of recife. Journal of Civil Engineering and Architecture, 20(1), 344-352. doi: 10.17265/1934-7359/2016.03.009.

17. Coutts D.R., Wang J. (2018): Monitoring and analysis of results for two strutted deep excavations using vibrating wire strain gauges. Tunnelling and Underground Space Technology, 16, 87-92. doi: 10.1016/S0886-7798(01) 00032-3

18. Loutas T. H., Panopoulou A., Roulias D., Kostopoulos V. (2012): Intelligent health monitoring of aerospace composite structures based on dynamic strain measurements. Expert Systems with Applications, 39, 8412-8422. doi: 10. 1016/j.eswa.2012.01.179

19. Kodur V. (2014): Properties of concrete at elevated temperatures. Scientific World Journal, 468510, 15. doi: 10.1155/ 2014/468510

20. Wang J. Y., Chen Z. Z., Wu K. (2019): Properties of calcium sulfoaluminate cement made ultra-high performance concrete: Tensile performance, acoustic emission monitoring of damage evolution and microstructure. Construction and Building Materials, 208, 767-779. doi: 10.1016/j. conbuildmat.2019.03.057

21. Li G., Zhang J., Song Z., Shi C., Zhang A. (2017): Improvement of workability and early strength of calcium sulphoaluminate cement at various temperature by chemical admixtures. Construction and Building Materials, 160, 427-439. doi: 10.1016/j.conbuildmat.2017.11.076

22. Zhang D., Xu D., Cheng X. (2009): Carbonation resistance of sulphoaluminate cement-based high performance concrete. Journal of Wuhan University of Technology-Mater, 450, 3-66. doi: 10.1007/s11595-009-4663-y 
23. Bu Y., Chang Z., Du J., Liu D. (2017): Experimental study on the thermal expansion property and mechanical performance of oil well cement with carbonaceous admixtures. RSC Advances, 450, 29240-29254. doi: 10.1039/ C7RA03504G

24. Pimienta P., Alonso M. C., McNamee R. J., Mindeguia J. C. (2017): Behavior of high-performance concrete at high temperatures: Some highlights. Journal of RILEM, 226, 45-52. doi: 10.21809/rilemtechlett.2017.53

25. Xu Q., Ji T., Yang Z., Ye Y. (2019): Preliminary investigation of artificial reef concrete with sulphoaluminate cement, marine sand and sea water. Construction and Building Materials, 211, 837-846. doi: 10.1016/j.conbuildmat.2019. 03.272

26. Li L., Wang R., Zhang S. (2019): Effect of curing temperature and relative humidity on the hydrates and porosity of calcium sulfoaluminate cement. Construction and Building Materials, 213, 627-636. doi: 10.1016/j.conbuildmat.2019. 04.044

27. Ioannou S., Paine K., Reig L., Quillin K. (2015). (2014): Performance chacteristics of concrete based on a ternary calcium sulphoaluminate-anhydrite-fly ash cement. Cement and Concrete Composites Journal, 201(18), 196-204. doi: 10.1016/j.cemconcomp.2014.08.009

28. Nilsen V., Pham L.T., Hibbard M., Klager A., Cramer S. M., Morgan D. (2019): Prediction of concrete coefficient of thermal expansion and other properties using machine learning. Construction and Building Materials, 220, 587-595. doi: 10.1016/j.conbuildmat.2019.05.006

29. Pelletier L., Winnefeld F., Lothenbach B. (2010). The ternary system Portland cement-calcium sulphoaluminateclinkeranhydrite: Hydration mechanism and mortar properties. Cement and Concrete Composites, 240, 497-507. doi: 1016/j.cemconcomp.2010.03.010

30. Wang S., Jian L., Shu Z., Wa J., Hua X., Chen L. (2019): Preparation, properties and hydration process of low temperature nano-composite cement slurry. Construction and Building Materials, 205, 434-442. Doi:10.1016/j. conbuildmat.2019.02.049

31. Arioz O. (2007): Effects of elevated temperatures on properties of concrete. Fire Safety Journal, 42(8), 516- 522. doi: 10.1016/j.firesaf.2007.01.003

32. Xie Q., Zhang L., Yin S., Zhang B., Wu Y. (2019): Effects of High Temperatures on the Physical and Mechanical Properties of Carbonated Ordinary Concrete. Advances in Material Science and Engineering, 5753232, 1-10. doi: $10.1155 / 2019 / 5753232$

32. Helal M. A., Heiza K. M. (2010): Effect of Fire and High Temperature on the Properties of Self Compacted Concrete. In: Ye L., Feng P., Yue Q. (eds) Advances in FRP Composites in Civil Engineering, pp.433-439. doi: 10.1007/978-3-64217487-2-94 